Relita Pebrina, Wiwit Sepvianti, Serafica Btari Christiyani Kusumaningrum, Rifail, Pengaruh Frekuensi Mengkonsumsi Kopi Dengan Kadar Hemoglobin Calon Pendonor Laki-Laki Di PMI Kabupaten Sleman

\title{
PENGARUH FREKUENSI MENGKONSUMSI KOPI DENGAN KADAR HEMOGLOBIN CALON PENDONOR LAKI-LAKI DI PMI KABUPATEN SLEMAN
}

\author{
Relita Pebrina ${ }^{1}$ \\ Prodi DIII Teknologi Bank Darah STIKes Guna Bangsa Yogyakarta \\ Corresponding author E-mail : relita.pebrina@gunabangsa.ac.id \\ Wiwit Sepvianti ${ }^{2}$ \\ Prodi DIII Teknologi Bank Darah STIKes Guna Bangsa Yogyakarta \\ Corresponding author E-mail : wiwit.sepvianti01@gmail.com \\ Serafica Btari Christiyani Kusumaningrum ${ }^{3}$ \\ Prodi DIII Teknologi Bank Darah STIKes Guna Bangsa Yogyakarta \\ Corresponding author E-mail : seraficabtarick@gmail.com \\ RIfail $^{4}$ \\ Prodi DIII Teknologi Bank Darah STIKes Guna Bangsa Yogyakarta \\ Corresponding author E-mail : rifailrustam@gmail.com
}

\begin{abstract}
ABSTRAK
Donor darah adalah proses pengambilan darah dari seseorang secara sukarela untuk disimpan di bank darah yang kemudian digunakan untuk keperluan transfusi darah. Sebelum pelaksanaan pengambilan darah (aftap), calon donor terlebih dahulu diseleksi untuk mengetahui apakah memenuhi syarat/ kriteria yang ditentukan. Seleksi donor diantaranya adalah pemeriksaan kadar hemoglobin $(\mathrm{Hb})$. Kadar $\mathrm{Hb}$ setiap orang berbeda-beda, hal ini dapat dipengaruhi oleh beberapa faktor salah satunya minuman yang populer saat ini adalah kopi. Tujuan penelitian ini adalah mengetahui pengaruh frekuensi minum kopi dengan kadar hemoglobin calon pendonor laki-laki. Jenis penelitian ini bersifat deskriptif korelational dengan pendekatan cross sectional. Sampel penelitian berjumlah 50 responden ditentukan dengan concecutive sampling. Hasil yang didapat dalam penelitian ini yaitu frekunesi mengkonsumsi kopi responden 4 kali dalam seminggu memiliki kadar $\mathrm{Hb}$ normal 40,0\% lebih banyak dari kadar $\mathrm{Hb}$ rendah $2,0 \%$ dan kadar $\mathrm{Hb}$ tinggi $0,0 \%$, sedangkan responden dengan perilaku $>4$ kali minum kopi dalam seminggu memiliki kadar $\mathrm{Hb}$ normal $30,0 \%$ lebih banyak dari kadar $\mathrm{Hb}$ rendah $4,0 \%$ dan kadar $\mathrm{Hb}$ tinggi $0,0 \%$. Responden dengan perilaku 6 kali minum kopi dalam seminggu memiliki kadar $\mathrm{Hb}$ normal 20,0\% lebih banyak dari kadar $\mathrm{Hb}$ rendah $4,0 \%$ dan kadar $\mathrm{Hb}$ tinggi $0,0 \%$. Kesimpulan penelitian ini adalah terdapat pengaruh frekuensi konsumsi kopi dengan kadar hemoglobin calon pendonor laki-laki dengan nilai signifikasi 0.000 .
\end{abstract}

Kata Kunci : Calon Pendonor, Kadar Hemoglobin, Kopi

\section{ABSTRACT}

A blood donor is a blood collection process from a person voluntarily, stored in a blood bank, then used for blood transfusion. Before blood draw, the first donors are selected to know whether they fulfil the specified criteria. Donor selection includes the examination of hemoglobin ( $\mathrm{Hb})$ levels. $\mathrm{Hb}$ levels are different for each person and influenced by several factors, such as drinking coffee. This study aimed to determine the effect of drinking coffee frequency on the hemoglobin level of male donors. The type of this study is a descriptive correlation with the cross-sectional approach. The research sample was 50 respondents of candidate donors and determined by consecutive sampling. The results of this study are that the frequency of respondents consuming coffee four times a week has normal $\mathrm{Hb}$ levels (40.0\%) more than low $\mathrm{Hb}$ levels (2.0\%) and high $\mathrm{Hb}$ levels $(0.0 \%)$. The respondent's frequency of $>4$ times a week consuming coffee has normal $\mathrm{Hb}$ levels $30.0 \%$ more than low $\mathrm{Hb}$ levels (4.0\%) and high $\mathrm{Hb}$ levels (0.0\%). The frequency of respondents that has $>6$ times a week of consuming coffee show normal $\mathrm{Hb}$ levels $20.0 \%$ more than low $\mathrm{Hb}$ levels (4.0\%) and high $\mathrm{Hb}$ levels (0.0\%). This study concludes that there is an effect of the 
Relita Pebrina, Wiwit Sepvianti, Serafica Btari Christiyani Kusumaningrum, Rifail, Pengaruh Frekuensi Mengkonsumsi Kopi Dengan Kadar Hemoglobin Calon Pendonor Laki-Laki Di PMI Kabupaten Sleman

frequency of coffee consumption on the hemoglobin level of male donors with a significance value of 0.000 .

Keywords : Prospective Donor, Hemoglobin Level, Coffee.

\section{PENDAHULUAN}

Donor darah adalah proses pengambilan darah dari seseorang secara sukarela untuk disimpan di bank darah yang kemudian digunakan untuk keperluan transfusi darah (Darajatun, 2008). Sebelum pelaksanaan pengambilan darah (aftap), calon donor terlebih dahulu diseleksi. Syarat/ kriteria penting dalam seleksi donor diantaranya adalah usia, berat badan, tekanan darah, suhu tubuh, kadar hemoglobin $(\mathrm{Hb})$, interval sejak penyumbangan terakhir, dan kondisi kesehatan saat ini (Permenkes, 2015).

Kadar hemoglobin sebagai faktor penting untuk memenuhi persyaratan calon pendonor dan dapat menyebabkan anemia (Tartowo dkk, 2010). Apabila kadar hemoglobin dibawah nilai normal pada saat mendonorkan darah maka gejala yang akan timbul pada pendonor antar lain pusing, lemah, letih, lelah, dan lesu. Apabila kadar hemoglobin diatas nilai normal pada saat mendonorkan darah, dapat mengakibatkan darah menjadi terlalu pekat atau kental, sehingga mengakibatkan menambahnya beban kerja jantung pada pasien penerima transfusi. Oleh sebab itu, kadar hemoglobin sangat penting untuk dijaga dalam keadaan normal agar pendonor dan penerima transfusi mendapatkan hasil yang optimal (Ranchman dan Aditya, 2013).

Penelitian ini dilakukan untuk mengetahui apakah terdapat pengaruh frekuensi mengkonsumsi kopi dengan kadar hemoglobin calon pendonor laki-laki di PMI Kabupaten Sleman. Hasil penelitian dapat digunakan sebagai pedoman dalam memberikan edukasi kepada masyarakat khususnya calon pendonor dalam menjaga kadar hemoglobin tetap normal, sehingga dapat memenuhi syarat dalam mendonorkan darahnya.

\section{METODE PENELITIAN}

Penelitian ini adalah penelitian kuantitatif dengan jenis penelitian deskriptif korelational. Desain penelitian ini menggunakan cross sectional. Populasi adalah calon pendonor darah pada bulan Juli-Agustus 2020 di PMI Kabupaten Sleman Yogyakarta yang ditentukan dengan teknik sampling yaitu concecutive sampling. Kemudian didapatkan 50 calon pendonor dengan kriteria usia 17-50 tahun, pendonor rutin maupun pendonor baru, dan pendonor mengkonsumsi kopi.

Teknik pemeriksaan kadar hemoglobin dalam penelitian ini menggunakan darah kapiler calon pendonor dan metode yang digunakan adalah automatic $\mathrm{Hb}$ meter. Sedangkan frekuensi mengkonsumsi kopi ditentukan dengan menggunakan kuesioner yang terdiri dari 15 pertanyaan dengan pilihan jawaban Ya dan Tidak.

Analisis data dilakukan secara sistematis dimulai dengan analisis univariat untuk mengetahui distribusi responden berdasarkan karakteristik responden, serta frekuensi responden berdasarkan frekuensi minum kopi dan kadar $\mathrm{Hb}$, kemudian selanjutkan dilakukan analisis bivariat dengan spearman's rho untuk mengetahui ada atau tidaknya pengaruh frekuensi konsumsi kopi dengan kadar $\mathrm{Hb}$ calon pendonor laki-laki.

\section{HASIL \\ Karakteristik Responden}

Analisis data univariat yang diuraikan berupa karakteristik responden yang meliputi usia, pekerjaan, dan golongan darah disajikan pada Tabel 1. 
Relita Pebrina, Wiwit Sepvianti, Serafica Btari Christiyani Kusumaningrum, Rifail, Pengaruh Frekuensi Mengkonsumsi Kopi Dengan Kadar Hemoglobin Calon Pendonor Laki-Laki Di PMI Kabupaten Sleman

Tabel 1. Distribusi Responden Berdasarkan Usia, Pekerjaan, dan Golongan Darah di PMI Kabupaten Sleman, Tahun 2020

\begin{tabular}{|c|c|c|c|}
\hline & Kategori & $\mathbf{N}$ & $\%$ \\
\hline \multirow[t]{4}{*}{ Usia } & $17-27$ & 18 & 36,0 \\
\hline & $28-38$ & 6 & 12,0 \\
\hline & $39-50$ & 26 & 52,0 \\
\hline & Total & 50 & 100 \\
\hline \multirow[t]{4}{*}{ Pekerjaan } & Wiraswasta & 30 & 60,0 \\
\hline & PNS & 7 & 14,0 \\
\hline & Mahasiswa & 13 & 26,0 \\
\hline & Total & 50 & 100 \\
\hline \multirow{5}{*}{$\begin{array}{c}\text { Golongan } \\
\text { Darah }\end{array}$} & A Positif & 11 & 22,0 \\
\hline & B Positif & 11 & 22,0 \\
\hline & AB Positif & 2 & 4,0 \\
\hline & O Positif & 26 & 52,0 \\
\hline & Total & 50 & 100 \\
\hline
\end{tabular}

Berdasarkan tabel di atas, didapatkan bahwa pada responden dengan usia terbanyak yaitu usia 39-50 tahun sebanyak 26 orang $(52,0 \%)$, pekerjaan terbanyak yaitu wiraswasta sebanyak 30 orang $(60,0 \%)$, dan golongan darah terbanyak yaitu $\mathrm{O}$ positif sebanyak 26 orang $(52,0 \%)$.

\section{Distribusi Responden Berdasarkan Perilaku Mengkonsumsi Kopi}

Dari 50 calon pendonor (responden) dikelompokkan menjadi tiga berdasarkan perilaku minum kopi seperti yang dapat dilihat pada Tabel 2.

Tabel 2. Distribusi Responden Berdasarkan Perilaku Mengkonsumsi Kopi di PMI Kabupaten Sleman, Tahun 2020

\begin{tabular}{ccc}
\hline $\begin{array}{c}\text { Perilaku Minum } \\
\text { Kopi }\end{array}$ & $\mathbf{N}$ & $\mathbf{\%}$ \\
\hline 4 kali seminggu & 21 & 42,0 \\
\hline$>4$ kali seminggu & 17 & 34,0 \\
\hline 6 kali seminggu & 12 & 24,0 \\
\hline Total & $\mathbf{5 0}$ & $\mathbf{1 0 0}$ \\
\hline
\end{tabular}

Berdasarkan tabel 2 didapatkan bahwa responden dalam penelitian sebagian besar pada frekuensi mengkonsumsi kopi 4 kali dalam seminggu sebanyak 21 responden $(42,0 \%)$.

\section{Distribusi Responden Berdasarkan Kadar Hemoglobin}

Dari 50 responden yang terlibat dilakukan pemeriksaan kadar hemoglobin. Hasil pemeriksaan dikelompokkan menjadi 2 yaitu kadar hemoglobin rendah dan tinggi seperti yang dapat dilihat pada Tabel 3 .

Tabel 3. Distribusi Responden Berdasarkan Kadar Hemoglobin di PMI Kabupaten Sleman, Tahun 2020

\begin{tabular}{ccc}
\hline $\begin{array}{c}\text { Kadar } \\
\text { Hemoglobin }\end{array}$ & $\mathbf{N}$ & $\mathbf{\%}$ \\
\hline Rendah & 5 & 10,0 \\
\hline Normal & 45 & 90,0 \\
\hline Total & $\mathbf{5 0}$ & $\mathbf{1 0 0}$ \\
\hline
\end{tabular}

Berdasarkan tabel 3 didapatkan bahwa responden dalam penelitian sebagian besar memiliki kadar hemoglobin yang normal sebanyak 45 responden (90,0\%). Pengkategorian kadar hemoglobin dalam penelitian terbagi menjadi kategori tinggi dengan kadar $\mathrm{Hb}>17 \mathrm{~g} / \mathrm{dL}$, kategori normal dengan kadar $\mathrm{Hb}$ 12,5-17 g/dL, dan kategori rendah dengan kadar $\mathrm{Hb}<12,5 \mathrm{~g} / \mathrm{dL}$.

\section{Pengaruh Frekuensi Minum Kopi dengan Kadar Hemoglobin Calon}

\section{Pendonor Laki-laki}

Hasil analisis bivariat pengaruh frekuensi minum kopi dengan kadar hemoglobin calon pendonor laki-laki disajikan pada Tabel 4 . 


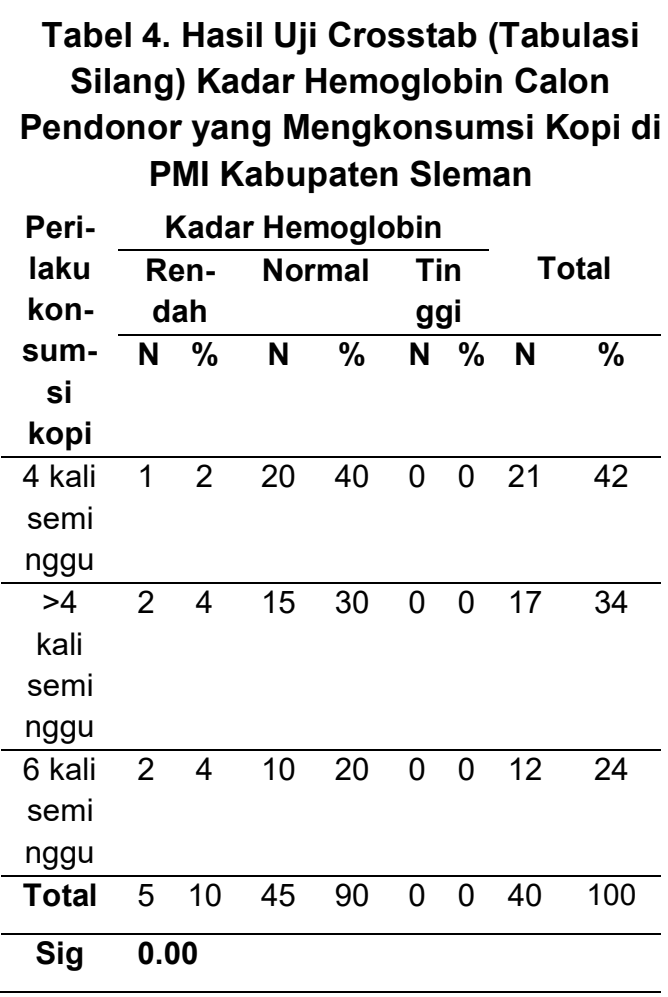

Berdasarkan data pada tabel 4. menunjukkan bahwa frekuensi mengkonsumsi kopi 4 kali dalam seminggu dengan kadar $\mathrm{Hb}$ normal $40,0 \%$ lebih banyak daripada kadar $\mathrm{Hb}$ rendah yaitu $2,0 \%$ dan kadar HB tinggi sebanyak $0,0 \%$, sedangkan pada responden dengan frekuensi mengkonsumsi kopi $>4$ kali dalam seminggu didapatkan kadar $\mathrm{Hb}$ normal $30,0 \%$ lebih banyak dari kadar $\mathrm{Hb}$ rendah yaitu $4,0 \%$ dan kadar $\mathrm{Hb}$ tinggi $0,0 \%$, dan pada responden dengan frekuensi mengkonsumsi kopi 6 kali dalam seminggu didapatkan kadar $\mathrm{Hb}$ normal $20,0 \%$ lebih banyak dari kadar $\mathrm{Hb}$ rendah yaitu $4,0 \%$ dan kadar $\mathrm{Hb}$ tinggi $0,0 \%$. Berdasarkan data tersebut disimpulkan bahwa responden yang mengkonsumsi kopi tidak mempengaruhi kadar $\mathrm{Hb}$ karena sebagian besar responden memiliki kadar $\mathrm{Hb}$ yang normal.

Berdasarkan hasil uji statistik dengan spearman's rho, didapatkan hasil signifikansi $0.000(<0.05)$ yang berarti bahwa terdapat pengaruh antara frekuensi minum kopi dengan kadar $\mathrm{Hb}$ calon pendonor laki-laki.

\section{PEMBAHASAN}

Kopi merupakan minuman yang dikonsumsi secara luas di seluruh dunia. Kopi banyak dikonsumsi sebagai minuman langsung setelah makan. Senyawa polifenol (tanin) dalam kopi dapat mengikat zat besi dalam lumen usus dengan membentuk kompleks yang tidak larut sehingga menghambat penyerapan zat besi (Stephenson, 1977). Minuman ini memiliki kandungan senyawa fenolik dan telah terbukti sangat menghambat penyerapan besi (Disler et al, 1975). Komponen lain dari kopi seperti asam klorogenat juga dapat mengganggu penyerapan zat besi (Gutnisky et al., 1992).

Jumlah senyawa-senyawa dalam kopi ini tergantung dari perbedaan jumlah dan merk kopi yang digunakan. Secangkir kopi (<150 $\mathrm{mL}$ ) mengurangi penyerapan zat besi hingga $<60 \%$. Namun, penyerapan zat besi ini juga tergantung dari kekentalan dari kopi yang dikonsumsi (Leif \& Lena, 2000). Selain itu, saat kopi disajikan dengan makanan yang mengandung $<100 \mathrm{~g}$ daging, penghambatan penyerapan zat besi berkurang sebesar $50 \%$ (Morck et al., 1983).

Zat besi memiliki beberapa fungsi vital dalam tubuh, yang berfungsi sebagai pembawa oksigen ke jaringan dari-paru melalui hemoglobin, sebagai pembawa elektron di dalam sel, dan sebagai bagian dari sistem enzim penting di berbagai jaringan.

Kekurangan zat besi umumnya dibagi menjadi tiga tahap. Tahap pertama adalah penurunan penyimpanan besi yang menginduksi konsentrasi feritin serum yang rendah. Fase berikut adalah eritropoiesis, kekurangan zat besi yang dicerminkan oleh penurunan saturasi transferin. Di tahap akhir, anemia terjadi dengan kadar hemoglobin yang rendah dan hematokrit (Cook \& Finch, 1979).

Kekurangan zat besi dapat didefinisikan sebagai menurunnya simpanan zat besi ditambah dengan menurunnya eritropoiesis (proses produksi sel darah merah). Hal ini terjadi pada kadar feritin serum $<15 \mathrm{mg} / \mathrm{L}$, 
yang mengakibatkan berkurangnya pembentukan hemoglobin.

Berdasarkan hasil penelitian, didapatkan bahwa responden yang intensitas minum kopinya lebih banyak yaitu dalam 6 kali seminggu, maka kadar hemoglobinnya semakin rendah (tabel 4). Hal ini sesuai dengan studi dari Garcia \& Milena (1987), menemukan bahwa kadar hemoglobin lebih rendah pada tikus yang terpajan kopi lebih tinggi dibandingkan dengan tikus yang terpajan kopi lebih rendah.

Defisiensi zat besi merupakan masalah nutrisi yang harus diberi pengawasan yang cermat. Defisiensi zat besi memiliki dampak yang signifikan terhadap kesejahteraan manusia baik pada tingkat individu maupun untuk perkembangan ekonomi suatu negara. Pada tingkat individu, kekurangan zat besi memiliki beberapa efek negatif pada fungsi penting daritubuh. Kekurangan zat besi dapat memperlambat pertumbuhan, menghambat perkembangan fisik dan mental, serta mengurangi kemampuan tubuh untuk mempertahankan dirinya sendiri. Ini berhubungan dengan gangguan respon imun,menurunkan resistensi terhadap infeksi dan meningkatkan morbiditas dan mortalitas. Kekurangan zat besi dalam keadaan parah enghasilkan anemia dan terkait dengan pengurangan kapasitas kerja, gangguan perilaku dan kinerja intelektual, keterlambatan adaptasi suhu tubuh terhadap lingkungan yang dingin, dan penurunan resistensi terhadap infeksi (Joung-Won, 2003). Kekurangan zat besi dalam jumlah besar dikaitkan dengan dampak negatif pada kualitas hidup, baik fisiologis dan sosial ekonomi, sehingga membutuhkan pendekatan yang komprehensif.

\section{KESIMPULAN}

Frekuensi minum kopi mempengaruhi kadar hemoglobin $(\mathrm{Hb})$ calon pendonor lakilaki. Rendahnya kadar $\mathrm{Hb}$ dapat mempengaruhi calon pendonor darah, yang menyebabkan gagalnya calon pendonor dalam mendonorkan darahnya. Oleh karena itu, diperlukan pemberian edukasi kepada masyarakat untuk menjaga kada hemoglobin dengan membatasi frekuensi konsumsi kopi.

\section{SARAN}

Untuk penelitian selanjutnya, perlu untuk meneliti tentang faktor-faktor lainnya yang mempengaruhi kadar $\mathrm{Hb}$ calon pendonor laki-laki dengan menggunakan metode penelitian yang berbeda.

\section{DAFTAR PUSTAKA}

Anonim. 2015. Peraturan Menteri Kesehatan Republik Indonesia Nomor 91 Tahun 2015 Tentang Standar Pelayanan Transfusi Darah. Jakarta

Cook JD, Finch CA(1979) : Assessing iron status of a population. Am J Clin Nutr 32 : 2115-2119

Daradjatun. (2008). Pedoman Pelayanan Transfusi Darah. Jakarta: UTD PMI Pustaka.

Disler PB, Lynch SR, Charlton RW, et al. The effect of tea on iron absorption. Gut 1975;16:193-200.

Garcia M, Milena L(1987) : Nutritional effects of coffee consumption during pregnancy and early lactation(Costa Rica). Thesis for docteral degree, University of California-Davis

Gutnisky A, Rizzo N, Castro ME, Garbossa $G$. The inhibitory action of chlorogenic acid on the intestinal iron absorption in rats. Acta Physiol Pharmacol Ther Latinoam 1992:42:139-46.

Joung-Won L, Wha-Jin H, Chung-Shil K. Iron Status and Its Relations with Nutrient Intake, Coffee Drinking, and Smoking in Korean Urban Adults. J Community Nutrition 5(1) : 44-50, 2003.

Leif $\mathrm{H}$, Lena $\mathrm{H}$. Prediction of dietary iron absorption: an algorithm for calculating absorption and bioavailability of dietary iron $^{1-3}$. Am J Clin Nutr 2000;71:1147-60.

Morck TA, Lynch SR, Cook JD. Inhibition of food iron absorption by coffee. Am J Clin Nutr 1983;37:416-20. 
Rachman, S.F., \& Aditya, N.R. (2013). Questions and Answer Donor Darah. Jakarta: Gramedia.

Stephenson PE. Physiologic and psychotropic effects of caffeine on man. I Am Diet Assoc 1977:71:240-7.

Tartowo, Ariyani R, Miradwiyana B, Aminah S, Sumiati, et al. (2010). Kesehatan Remaja Problem dan Solusinya. Jakarta: Salemba Medika. 